\title{
Phytoremediation: A way towards sustainable Agriculture
}

\author{
Pushpikka Udawat ${ }^{1}$, Jogendra Singh ${ }^{2}$
}

\author{
${ }^{1}$ Department of Biotechnology, JRN Rajasthan Vidyapeeth, Udaipur, India \\ ${ }^{2}$ All India Coordinated Research Project on National Seed Project (Crops), Rajasthan Agricultural Research Institute, Sri Karan Narendra \\ Agriculture University, Jaipur, India
}

\begin{abstract}
Phytoremediation means utilizing the potential of a variety of plants to remediate soil, sludge, sediment and water (surface water and underground aquifers) contaminated with heavy metals at the point or non-point sources. Phytoremediation is solar energy-driven technology, eco-friendly and a cost-effective way of making soil and water pollutants free. It is a process of onsite remediation by using different biological processes of plants. Phytoremediation is known widely by different terms viz., green-remediation, botanicremediation, agro-remediation, and vegetative-remediation, etc. Pollutants occur in different forms, like organic, inorganic, metallic and non-metallic, etc. Plants can be utilized for phytoremediation of heavy metal polluted soil and water resources. This review gives current understanding of the mechanism of heavy metal remediation by different plant species, therefore encouraging research and development in this area. Phytoremediation further needs a profound understanding of the underlying mechanism and requires pilot level as well as field level studies.
\end{abstract}

Keywords-Phytoremediation, Sustainable agriculture, Heavy metals, Eco-friendly.

\section{INTRODUCTION}

Phytoremediation is a dynamic process that eventually degrades or extracts pollutants in different proportions as they are hazardous and toxic to all living beings. The pollutants are degraded either through accumulation, filtration or dissipation. In the current scenario, the need of the hour is realizing the consequences of heavy metal pollutants in soil and water (Kaur, 2018). Heavy metal pollutants, the half-life is much more than that of organic pollutants like pesticides and petroleum by-products. Uranium in groundwater aquifers of Rajasthan is a great concern to environmentalists as in some or other ways it is affecting the natural occurrence of biogeochemical cycles (Daud et al., 2018). As different phases of the industrial revolution have passed, a variety of remediation technologies have also come into the market to deal with a variety of pollutants. Out of these contaminants, heavy metals like Uranium pose a great threat to the surrounding environment (Papazogloua and Fernandob, 2017). Due to mining and milling, radionuclide contaminants is prevalent in subsurface sediments throughout India. Due to the overexploitation of underground water resources, the water level has declined beyond environmentally acceptable and recoverable levels. Subsequently, heavy metals have found its way to the subsurface level thus entered into water and soil, contaminated them as a result of waste-disposal practices (Bora and Sarma, 2020).

Table 1: Different Plants showing Phytoremediation Potential

\begin{tabular}{|l|c|c|c|c|}
\hline Metal & Plant & Mechanism & Medium & Reference \\
\hline Zn, Cd & Thlaspi caerulescens & Phytoaccumulation & Soil/Water & Robinson et al., 1998 \\
\hline Trinitrotoluene (TNT) & Myriophyllum aquaticum & Phytoextraction & Hydroponic & Bhadra et al., 1999 \\
\hline
\end{tabular}


International Journal of Environment, Agriculture and Biotechnology, 5(4)

Jul-Aug, 2020 / Available: https://ijeab.com/

\begin{tabular}{|c|c|c|c|c|}
\hline Ethanol blended Gasoline & Weeping willow & Rhizofiltration & Water & $\begin{array}{l}\text { Corseuil and Fabio, } \\
2001\end{array}$ \\
\hline TNT, Pyrene, Aroclor 1248 & $\begin{array}{l}\text { Festuca arundinacea } \\
\text { Schreb. }\end{array}$ & Phytoextraction & Soil & $\begin{array}{l}\text { Chekol and Vough, } \\
2002\end{array}$ \\
\hline $\begin{array}{l}\text { Polycyclic Aromatic Hydrocarbons } \\
\text { (PAHs) }\end{array}$ & Clover and Ryegrass & Phytoextraction & Soil & Joner and Leyval, 2003 \\
\hline $\begin{array}{l}\text { Polycyclic Aromatic Hydrocarbons } \\
\text { (PAHs) }\end{array}$ & Meliotus officinalis & Phytoaccumulation & Soil & Parrish et al., 2004 \\
\hline $\mathrm{Zn}, \mathrm{Cd}, \mathrm{Cu}$ & $\begin{array}{c}\text { Agricultural Crops, Woody } \\
\text { Plants }\end{array}$ & Phytoaccumulation & Soil & Kayser et al., 2004 \\
\hline $\mathrm{Se}$ & Brassica juncea L. & Phytoextraction & Soil & Banuelos et al., 2005 \\
\hline Herbicides & Transgenic Oryza Sativa & Phytoextraction & Soil & $\begin{array}{l}\text { Kawahigashiet al., } \\
2006\end{array}$ \\
\hline $\mathrm{Hg}$ & $\begin{array}{c}\text { Chloroplast Tobacco } \\
\text { Transgenic }\end{array}$ & Phytoaccumulation & Soil & Hussein et al., 2007 \\
\hline $\mathrm{Hg}$ & Polypogon monospeliensis & Phytoextraction & Soil & Su et al., 2008 \\
\hline $\mathrm{Pb}$ & Scrophularia canina & $\begin{array}{c}\text { Phytoextraction } \\
\text { Phytostabilization }\end{array}$ & Mining Site & Cao et al., 2009 \\
\hline $\mathrm{Pb}, \mathrm{Zn}, \mathrm{Cd}$ & Common sunflower & Phytoaccumulation & Soil & Mukhtar et al., 2010 \\
\hline Radionuclides & Wolffia arrhiza & Rhizofiltration & Water & Louis et al., 2010 \\
\hline $\mathrm{Cr}$ & Switch grass & Phytoextraction & Soil & Li et al., 2011 \\
\hline $\mathrm{Ar}$ & Ludwigia octavalvis & Phytoextraction & Soil & Totah et al., 2012 \\
\hline Heavy Metals & Salsola soda & $\begin{array}{c}\text { Phytoextraction } \\
\text { Phytostabilization }\end{array}$ & Soil & Lorestani et al., 2013 \\
\hline $\mathrm{Cd}, \mathrm{Ni}, \mathrm{Cu}$ & Indian hemp & Phytoaccumulation & Soil & Girdhar et al., 2014 \\
\hline $\mathrm{Cu}, \mathrm{Zn}$ & Phalaris arundinacea $\mathrm{L}$. & Phytoextraction & Water & $\begin{array}{l}\text { Polechonska and Klink, } \\
2014\end{array}$ \\
\hline $\mathrm{Co}, \mathrm{Cr}$ & Pennisetum purpureum & Phytoaccumulation & Soil & $\begin{array}{l}\text { Lotfy and Mostafa, } \\
2014\end{array}$ \\
\hline Heavy Metals & Annual wageweed & Phytostabilization & Soil & Lum et al., 2014 \\
\hline $\mathrm{Cd}, \mathrm{Pb}, \mathrm{Zn}, \mathrm{Cu}$ & Paulownia & Phytoaccumulation & Soil & Tzvetkova et al., 2015 \\
\hline $\mathrm{Pb}, \mathrm{Ni}$ & Brassica nigra & Phytoextraction & Soil/Water & Singh et al., 2015 \\
\hline $\mathrm{Ar}$ & Pteris vittata & Phytoextraction & Soil/Water & Lampis et al., 2015 \\
\hline $\mathrm{Ar}$ & Lupinus microcarpus & Phytoaccumulation & Soil & Diaz et al., 2016 \\
\hline $\mathrm{Cd}$ & Tradescantia pallida & Phytostabilization & Soil/Water & $\begin{array}{l}\text { Areekijseree } \text { et al., } \\
2016\end{array}$ \\
\hline $\mathrm{U}$ & Carex nebrascensis & Phytoextraction & Water & $\begin{array}{c}\text { Gaikwad and Gavande, } \\
2017\end{array}$ \\
\hline
\end{tabular}


International Journal of Environment, Agriculture and Biotechnology, 5(4)

Jul-Aug, 2020 / Available: https://ijeab.com/

\begin{tabular}{|l|c|c|c|c|}
\hline Heavy Metals & Cannabis Sativa & Phytostabilization & Soil & Kumar et al., 2017 \\
\hline Landfill Leachate & Lemna minor & Phytoextraction & Soil/Water & Daud et al., 2018 \\
\hline $\mathrm{Cu}$ & Bruguiera cylindrica L. & Phytostabilization & Soil & $\begin{array}{c}\text { Sruthi and Puthur, } \\
2019\end{array}$ \\
\hline Heavy Metals & $\begin{array}{c}\text { Native Herbaceous } \\
\text { Macrophytes }\end{array}$ & Phytostabilization & Wetlands & Bora and Sarma, 2020 \\
\hline
\end{tabular}

\section{PHYTOREMEDIATION}

The underlying methods encompassing phytoremediation are degradation, accumulation, dissipation, immobilization, etc. The different ways of phytoremediation are described individually in this review. The process of phytoremediation can be applied to a variety of potential pollutants, viz., petroleum hydrocarbons, organic contaminants, chlorinated compounds, heavy metals, radionuclides, agro-waste, pentachlorophenol (PCP), polycyclic aromatic hydrocarbons (PAHs), etc (Pivetz, 2001). The term hyper accumulator was coined and used for the first time by the late Professor, Robert Brooks (Brooks et al., 1980). Hyper accumulators as per Brooks and his co-workers are defined as plants that can accumulate different metalloids above the threshold concentration of 10,000 to $100 \mathrm{mg} / \mathrm{kg}$ (shoot dry weight) (Baker and Brooks, 1989; Brown et al., 1994). Moreover, a particular plant species will be called hyper accumulator, if it is able to accumulate more than $0.1 \%$ of heavy metals of its dry weight (Kirkwood, 2002). However, the plant should show tolerance to heavy metals without having necrotic, chlorotic or any other cellular damage symptoms (Titah et al., 2012; Kumar and Chauhan, 2016).

If plants accumulate more than $51 \%$ of heavy metal of its dry weight overnight than it is considered as a potential agent for phytoremediation. The hyper accumulators are mainly documented from particular plant families, viz., Brassicaceae, Cunouniaceae, Caryophyllaceae, Asteraceae, Euphorbiaceae, Cyperaceae, Fabaceae, Lamiaceae, Violaceae, Poaceae, etc (Padmavathiamma and $\mathrm{Li}$, 2007). A plant with phytoremediation potential has to have specific qualities, viz., high growth rate, high biomass accumulation, elongated and adventitious root system, high bioaccumulation coefficient, fantastic metal-accumulating strength, etc. Till now, around 500 plant species have been documented as hyper accumulators and recommended for phytoremediation of polluted soil and water resources (Bhaskar and Rajanna, 2018). Additionally, diverse plant species (crops as well as woody plants along with transgenic lines) showing phytoremediation capabilities are enlisted in Table 1.

\section{Factors affecting Uptake Mechanism}

1. Plant Species 2. Properties of Medium 3. Root Zone

4. Vegetative Uptake 5. Addition of Chelating Agent

\section{PHYTOEXTRACTION}

The literal meaning of phytoextraction is, "Phyto" meaning plant and "Extraction" meaning removing (Henry and Fabio, 2001) (as shown in Fig.1). The process of phytoextraction involves translocating the pollutants from the rhizosphere to different plant parts, viz., shoot, leaf, stem, flower, etc. Few plant species have the potential to extract both essential $(\mathrm{Cu}$, $\mathrm{Mg}, \mathrm{Mo}, \mathrm{K}, \mathrm{Fe}, \mathrm{Mn}, \mathrm{Ni}, \mathrm{P}$, and $\mathrm{Zn}$ ) as well as non-essential metals ( $\mathrm{Se}, \mathrm{B}, \mathrm{Cd}, \mathrm{Co}, \mathrm{Cr}, \mathrm{Ag}$, and $\mathrm{Hg}$ ). Essential metals are those required by plants in optimum amounts for their growth and development, whereas non-essential metals are toxic even in low amounts (Tang et al., 2019; Gupta et al., 2020). 


\section{Different Modes of Phytoremediation}

\section{Phytovolatilization}

Phytoextraction
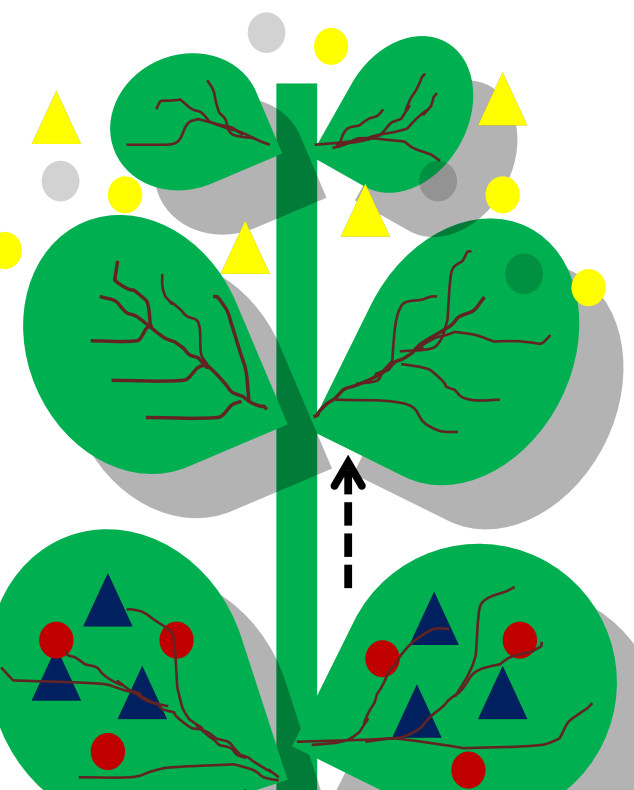

\section{ts/Contaminants}

\section{Rhizofilt}

\section{Phytostabilizatio.}

Fig. 1: Different Modes of Phytoremediation

\section{RHIZOFILTRATION}

The ability of plants to filtrate contaminated water aquifer, surface water, and wastewater with heavy metals, agri-waste (Pesticides and Insecticides) through a bunch of roots or adventitious root is known as Rhizofiltration (Akob et al., 2007) (as shown in figure 1). Therefore, it is a modified phytoextraction method by using aquatic vegetation and adsorption of toxic elements primarily into the root zone (Beans, 2017). Initially, instead of soil, plants are grown in the hydroponic system and allowed to acclimatize in contaminated water under greenhouse conditions (Bibi et al., 2016). Subsequently, plants are planted on the contaminated sites, where the adventitious roots will accumulate the toxins from the rhizosphere to roots and then transmission to the 
aerial parts (Cho and Choo, 2019). The factors affecting the rate of adsorption, concentrate, precipitate onto root surface are the concentration of hazardous elements and plants dry weight. A set of plants used for hemofiltration are sunflower, tobacco, spinach, rye and Indian mustard (Soliman and Sugiyama, 2016). The most widely used choice for hemofiltration is terrestrial plants as they possess fibrous roots and rapid growth rate. The process of hemofiltration can be applied to wetlands, ponds and constructed water tanks. The ultimate fate of rhizofiltered pollutants is rhizodegradation (degradation in roots) and then phytodegradation (degradation in aerial parts of the plant) (Gonzalez et al., 2017).

\section{PHYTOSTABILIZATION}

It is the process in which plants store toxic metals at a particular site in a non-toxic metallic and immobile form, hence the metal is not able to mobilize to other organelles thus do not interfere with cellular metabolism (as shown in figure 1). Subsequently, the rate of migration of metals gets reduced (Oscar et al., 2016). Therefore, the soil need not be free from contaminants and on-site phytoremediation can be done with potential plants whose roots are capable of growing under polluted soils and thus helps in metal immobilization through root adsorption, metal precipitation, complex formation or reduction (Barcel and Poschenrieder, 2003). Additionally, the metals are stabilized within plant cells from mobile and toxic to immobile form, for example, toxic $\mathrm{Cr}^{6+}$ gets transformed to $\mathrm{Cr}^{3+}$, which is less mobile (James, 2001). The process of phytostabilization seems to be more efficient in the case of fine soils having high organic matter content (Berti and Cunningham, 2000).

\section{PHYTOVOLATIZATION}

In this process, plants utilize transpiration to converts heavy metals from more toxic form to less toxic volatile form, thus eradicate pollutants from soil and water (as shown in figure 1). The metals that get volatized through transpiration are, Arsenic, Mercury ( $\mathrm{Hg}$, more toxic to $\mathrm{Hg}^{2+}$, less toxic) and Selenium (Se, more toxic to $\left(\mathrm{CH}_{3}\right) 2 \mathrm{Se}, 600$ times less toxic), etc. Plant species that adopt the phytovolatilization process for removing contaminants are Arabidopsis thaliana and Musk grass.

\section{CONCLUSION}

Phytoremediation of contaminated soil and water resources has proved to be a sustainable technology and emerged as one of the eco-friendly agriculture practices. Phytoremediation has a high potential when compared with other traditional and conventional approaches for heavy metal removal. A variety of plant species have shown high performance in hyper accumulation of heavy metals viz., Cadmium, Copper, Mercury, Lead, Zinc, and Uranium, etc. Plants belonging to different families have different abilities to accumulate, detoxify and sequester a variety of heavy metals. However, the phytoremediation research studies are very few in number predominantly at field level. Hence, the need of the hour for phytoremediation research is on developing novel experimental design both at pilot as well as field level in polluted soil and water resources. Furthermore, the procedure for removal of heavy metals augmented biomass necessities to be additionally developed. Additionally, the current circumstances stresses on using the amalgamation and collaboration of traditional methods along with recent phytoremediation practices to deliver an advanced way of heavy metal remediation from both contaminated soil and water resources.

\section{DISCLOSURE}

The manuscript does not have any conflict of interest with any author, organization, institute, etc.

\section{REFERENCES}

[1] Akob DM, Mills HJ, Kostka JE. Metabolically active microbial communities in uranium contaminated subsurface sediments. FEMS Microbiol Ecol, 59: 95-107, 2007.

[2] Areekijseree M, Bunyakitjinda V, Euawong N, Srinark C. Effect of Cadmium accumulation on Purple Heart, (Tradescantia pallida): An investigation by SEI/EDX smiling program X-ray images. Veridian E-Journal, 3(6): ISSN 24081248, 2016.

[3] Baker A and Brooks R. Terrestrial Higher Plants Which Hyperaccumulate Metallic Elements, A Review of Their Distribution, E. Ecol Phytochem Biorecovery, 1, 1989.

[4] Banuelos G, Terry N, LeDuc DL, Pilon-Smits EAH, Mackey B. Field Trial of Transgenic Indian Mustard Plants Shows Enhanced Phytoremediation of Selenium-Contaminated Sediment. Environ Sci Technol, 39(6): 1771-1777, 2005.

[5] Barcel J, Poschenrieder C. "Phytoremediation: principles and perspectives," Contributions to Science, 2 (3): 333-344, 2003. 
[6] Beans C, Science Writer. Phytoremediation advances in the lab but lags in the field. PNAS, 114 (29): 7475-7477, 2017.

[7] Bhadra R, Spanggord RJ, Wayment DG, Hughes JB, Shanks JV. Characterization of Oxidation Products of TNT Metabolism in Aquatic Phytoremediation Systems of Myriophyllum aquaticum. Env Sci \& Tech, 33 (19): 33543361, 1999.

[8] Bhaskar K, Rajanna L. Phytosociological Analysis in SemiArid Region of India: A Case Study from Yadgir District, Karnataka. J Biodiversity, 9(1-2): 14-24, 2018.

[9] Bibi S, Jabeen R, Hayee AA. A Review: Phytoremediation: Using Aquatic Plants to Clean Up Polluted Water. Int J Current Research, 8 (8): 35561-35564, 2016.

[10] Bora MS, Sarma KP. Phytoremediation of Heavy Metals/Metalloids by Native Herbaceous Macrophytes of Wetlands: Current Research and Perspectives, 261-284, 2020.

[11] Brown SL, Chaney RL, Angle JS, Baker AJM. Phytoremediation Potential of Thlaspi caerulescens and Bladder Campion for Zinc- and Cadmium-Contaminated Soil. J. Environ Qual, 23: 1151-1157, 1994.

[12] Cao A, Carucci A, Lai T, Bacchetta G, Casti M. Use of native species and biodegradable chelating agents in the phytoremediation of abandoned mining areas. J Chemi Tech Biotechnol, 84 (6): 884-889, 2009.

[13] Chekol T,Vough LR. Assessing the Phytoremediation Potential of Tall Fescue and Sericea Lespedeza for Organic Contaminants in Soil. J Env Cleanup Costs, Tech, \& Tech, 2002.

[14] ChoBW, Choo CO. Geochemical Behavior of Uranium and Radon inGroundwater of Jurassic Granite Area, Icheon,Middle Korea. Water, 11: 1278,2019.

[15] Daud MK, Ali S, Abbas Z, Zaheer IE, Riaz MA, Malik A, Afzal Hussain, Rizwan $\quad$ M, Zia-ur-Rehman M, Zhu SJ. Potential of Duckweed (Lemna minor) for the Phytoremediation of Landfill Leachate. J Chemistry, Article ID: 3951540, 2018.

[16] Gaikwad RS, Gavande S. Study of the Phytoremediation Process for Removal of Contaminants from Waste Water.Int $\mathbf{J}$ Sci and Res, 6, 2017.

[17] Gonzalez A, Gil-Diaz MM, Lobo CM. J Soils Sediments, 17: 1403, 2017.

[18] Gupta DK, Chatterjee S, Mitra A, Voronina A, Walther C. Uranium and Plants: Elemental Translocation and Phytoremediation Approaches. In: Gupta D., Walther C. (eds) Uranium in Plants and the Environment. Radionuclides and Heavy Metals in the Environment. Springer, Cham, 2020.

[19] Henry C, Fabio M. Phytoremediation potential of willow trees for aquifers contaminated with ethanol-blended gasoline. Water Res, 35: 3013-3017, 2001.

[20] Hussein HS, Ruiz ON, Terry N, Daniell H. Phytoremediation of Mercury and Organomercurials in Chloroplast Transgenic Plants: Enhanced Root Uptake, Translocation to Shoots, and Volatilization. Env Sci Technol, 41 (24): 8439-8446, 2007.
[21] Joner EJ, Leyval C. Rhizosphere Gradients of Polycyclic Aromatic Hydrocarbon (PAH) Dissipation in Two Industrial Soils and the Impact of Arbuscular mycorrhiza. Env Sci \& Tech, 37 (11): 2371-2375, 2003.

[22] Kaur L. Accumulation potential of Indian mustard (Brassica juncea var. arawali) and fenugreek (Trigonella foenumgraecum L.) planted on Lead and Nickel contaminated soil. Tropical Plant Research, 5(2): 217-223, 2018.

[23] Kawahigashi H, Hirose S, Ohkawa H, Ohkawa Y. Phytoremediation of the Herbicides Atrazine and Metolachlor by Transgenic Rice Plants Expressing Human CYP1A1, CYP2B6, and CYP2C19. J Agricultural and Food Chemistry, 54 (8): 2985-2991, 2006.

[24] Kayser A, Wenger K, Keller A, Attinger W, Felix HR, Gupta SK, Schulin R. Enhancement of Phytoextraction of Zn, Cd, and $\mathrm{Cu}$ from Calcareous Soil: The Use of NTA and Sulfur Amendments. Env Sci Technol, 34 (9): 1778-1783, 2004.

[25] Kirkwood N. Here come the hyperaccumulators. Harvard Design Magazine Fall/Winter, 1-4, 2002.

[26] Kumar D, Chauhan DK. Seedling Morphology of two important Medicinal Plant Species of Wrightia R.Br. (Apocynaceae) and its Taxonomic Significance. ISSN 03765561, Geophytology 46(2): 157-162, 2016.

[27] Kumar S, Singh R, Kumar V, Rani A, Jain R. Cannabis sativa: A Plant Suitable for Phytoremediation and Bioenergy Production. In: Bauddh K, Singh B, Korstad J. (eds) Phytoremediation Potential of Bioenergy Plants. Springer, Singapore, 2017.

[28] Lampis S, Santi C, Ciurli A, Andreolli M, Vallini G.Promotion of arsenic phytoextraction efficiency in the fern Pteris vittata by the inoculation of As-resistant bacteria: a soil bioremediation perspective.6 (80), 2015.

[29] Li C, Wang QH, Xiao B, Li YF. Phytoremediation potential of switch grass (Panicum virgatum L.) for Cr-polluted soil. Int Symposium on Water Resource and Environmental Protection, 2011.

[30] Lorestani $\quad$ B, Yousefi N, Cheraghi M, Farmany A. Phytoextraction and phytostabilization potential of plants grown in the vicinity of heavy metal-contaminated soils: a case study at an industrial town site. Environ Monit Assess., 185 (12): 10217-23, 2013.

[31] Lotfy SM, Mostafa AZ. J Geochemical Exploration, 144: 367373, 2014.

[32] Lum AF, Ngwa ES, Chikoye D, Suh CE. Phytoremediation potential of weeds in heavy metal contaminated soils of the Bassa Industrial Zone of Douala, Cameroon. Int $\mathbf{J}$ Phytoremediation, 16(3): 302-19, 2014.

[33] Oscar D, Yasna T, Olivares P, Cazanga R, Segura M, Peredo $\mathrm{R}$, Santiago. Lupinus microcarpus Growing in ArsenicAgricultural Soils from Chile: Toxic Effects and It Potential Use as Phytoremediator Plant. J Env Prot, 07: 116-128, 2016. 
[34] Padmavathiamma PK, Li LY."Phytoremediation technology: hyper-accumulationmetals in plants. Water, Air\& Soil Pollution, 184(1-4): 105-126, 2007.

[35] Papazogloua EG,Fernandob AL. Preliminary studies on the growth, tolerance and phytoremediation ability of sugarbeet (Beta vulgaris L.) grown on heavy metal contaminated soil. Industrial Crops and Products, 107 (15): 463-471, 2017.

[36] Parrish ZD, Banks MK, Schwab AP. Effectiveness of Phytoremediation as a Secondary Treatment for Polycyclic Aromatic Hydrocarbons (PAHs) in Composted Soil, Int J Phytoremediation, 6 (2): 119-137, 2004.

[37] Polechonska L,Klink A. Trace metal bioindication and phytoremediation potentialities of Phalaris arundinacea L. (reed canary grass). J Geochem Expl, 146: 27-33, 2014.

[38] Robinson BH, Leblanc M, Petit D, Brooks RR, Kirkman JH, Gregg PEH. The potential of Thlaspi caerulescens for phytoremediation of contaminated soils. Plant and Soil,203:47-56, 1998.

[39] Singh UV, Abhishek A, Bhaskar M, Tandan N, Ansari NG, Singh NP. Phyto-extraction of heavy metals and biochemical changes with Brassica nigra L. grown in rayon grade paper mill effluent irrigated soil. ISSN 0973-2063 (online), 09738894 (print), Bioinfo, 11(3): 138-144,2015.

[40] Soliman WS, Sugiyama SI. Phytoremediation and tolerance capacity of Moringa olifera to Cadmium and its relation to nutrients content. Poll Res., 35 (1): 23-27, 2016.

[41] Sruthi P, Puthur JT. Characterization of physiochemical and anatomical features associated with enhanced phytostabilization of copper in Bruguiera cylindrica (L.) Blume. Int J Phytoremediation, 21 (14): 1423-1441, 2019.

[42] Su Y, Han FX, Chen J, Sridhar BB, Monts DL.Phytoextraction and accumulation of mercury in three plant species: Indian mustard (Brassica juncea), beard grass (Polypogon monospeliensis), and Chinese brake fern (Pteris vittata). Int $\mathbf{J}$ Phytoremediation., 10(6): 547-60, 2008.

[43] Tang L, Hamid Y, Zehra A, Sahito ZA, He Z, Hussain B, Gurajala HK, Yang X.Characterization of fava bean (Vicia faba L.) genotypes for phytoremediation of cadmium and lead co-contaminated soils coupled with agroproduction.Ecotoxicol Environ Saf, 30 (171):190-198, 2019.

[44] Titah HS, Abdullah SRH, Idris M, Anuar N, Basri H, Mukhlisin M. Arsenic Range Finding Phytotoxicity Test Against Ludwigia octovalvis as First Step in Phytoremediation. Research JEnv Toxicol, 6: 151-159, 2012.

[45] Tzvetkova N, Miladinova K, Ivanova K, Georgieva T, Geneva M, Markovska Y. Possibility for using of two Paulownia lines as a tool for remediation of heavy metal contaminated soil. J Environ Biol., 36: 145-51, 2015. 